\title{
Body Challenges - Between Architectural Scale Models and Architectural Objects
}

\author{
By João Miguel Couto Duarte*
}

\begin{abstract}
"The domain of inhabitable objects that architecture claims as its own finds its first intimation in the model. The model purports to present architecture, not represent it." Scale models have long been recognized as a powerful device for envisioning architecture, having - as architectural objects do - a three-dimensional existence and involving - as said objects also do - a construction process. That is why scale models are still trusted as architecture closest representation, even if the relationship between one and the other must be acknowledged as a strictly arbitrary one, since all relationships of representation are arbitrary. But some scale models seem to aim to question their representational condition. By virtue of their size and also of the materials they are built with, some scale models compel one to enter into them rather than just encounter them, allowing for a comprehensive experience that emulates the experience desirably made possible by the architectural object they represent. The body is challenged to live inside those scale models, to immerse in their interior, even to move through it, with such scale models becoming habitable objects. And even if these scale models do not always find regular use, the history of architecture documents their adoption as a pervasive practice. One question must thus be poised: are such objects still representations, or have they crossed a line and become architectural objects? This paper sets out to discuss the role of the body in the distinction between an architectural object and certain scale models, thus contributing to the inderstanding of both. Rather than on a set of intrinsic features pertaining to each one of those objects, the distinction between one and the other will be sought on how those objects are signified. Those objects become either an architectural object or a scale model depending on how the body challenges itself to get embraced by them.
\end{abstract}

\section{Initial Considerations}

"The domain of inhabitable objects that architecture claims as its own finds its first intimation in the model. The model purports to present architecture, not represent it." 2

The musealisation of the eleventh century Islamic residential structures found in the archaeological site of Praça Nova do Castelo de São Jorge, in Lisbon, designed by João Luís Carrilho da Graça Architects in $2008,{ }^{3}$ is quite singular in appearance (Figure 1).

\footnotetext{
*Assistant Professor/Research Fellow, Lusíada University, Lisbon/CITAD, Lusíada University, Lisbon, Portugal.

1. C. Hubert, "The Ruins of Representation," in Idea as Model (ed.) K. Frampton and S. Kolbowski (New York: Institute for Architecture and Urban Studies and Rizzoli International Publications, 1981), 17.

2. Ibid.

3. The musealisation of the Archaeological Site of Praça Nova do Castelo de São Jorge in Lisbon was commissioned by EGEAC - Empresa de Gestão de Equipamentos e Animação
} 


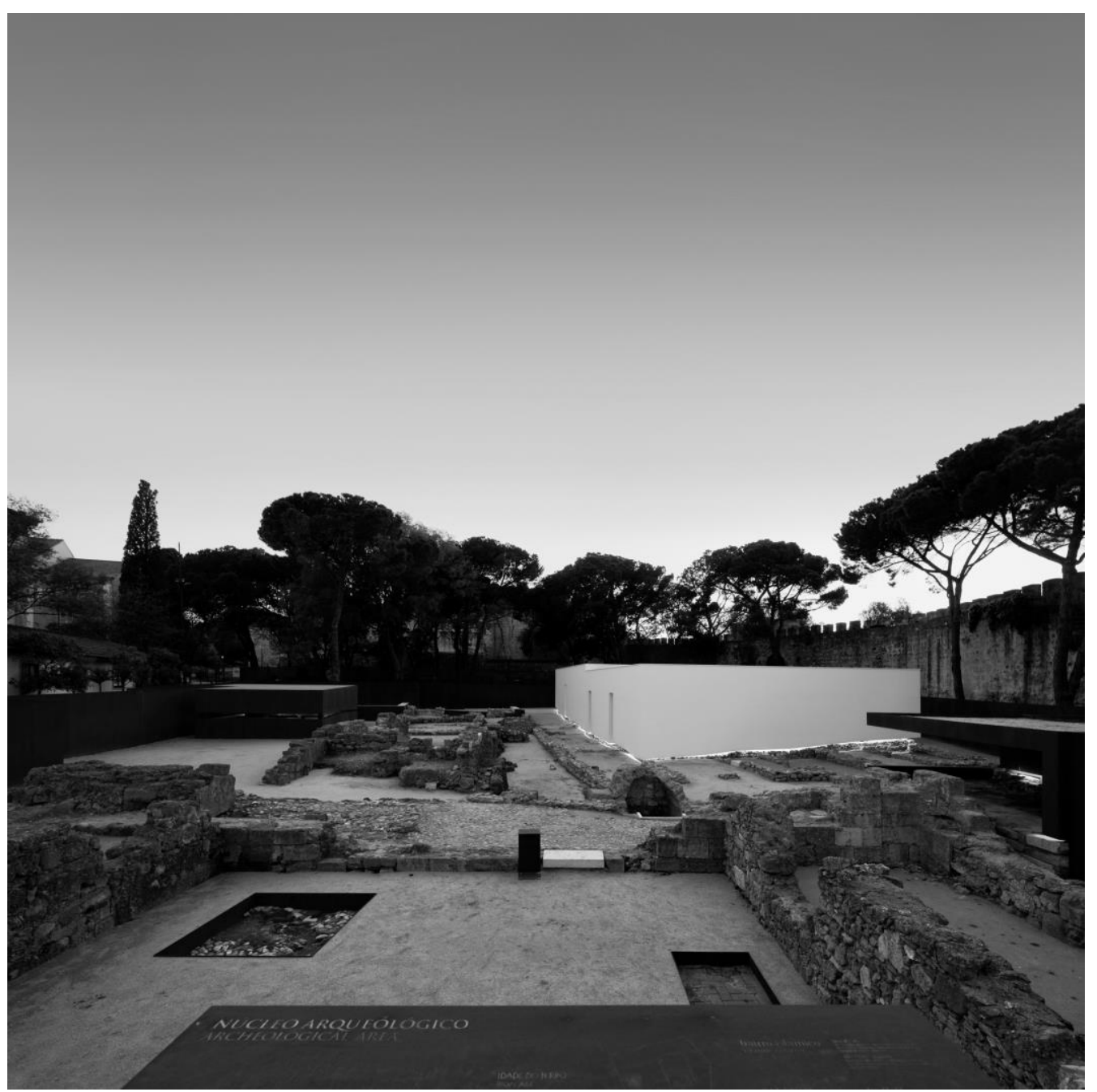

Figure 1. Musealisation of Islamic Residential Structures, Praça Nova do Castelo de São Jorge, Lisbon

Photo: Fernando Guerra| FG+SG.

The design presents an elementary white volume consisting of plain surfaces punctuated by just a few narrow apertures, the simplicity of its shape and the smoothness of its walls contrasting with the irregularity of the surrounding archaeological remains and the roughness of the materials of the structures accompanying them. The volume seams to float over the unearthed walls it is meant to protect, its supporting structure remainining unnoticed. Inside, a

Cultural, a Lisbon City Council-owned company responsible for managing some of the city's cultural spaces. The archeological works on Praça Nova began in 1996, revealing the remains of a settlement dating back to the Iron Age (the first known human settlement in the place that eventually became the city of Lisbon), the medieval Muslim occupation composed of two dwellings and a fifteenth century palace. The project was designed and built from 2008 to 2010, receiving the Piranesi Prix de Rome in 2010. According to the author, the "work addressed the issues of protection, revelation and interpretation of the palimpsest that is intrinsic to any such excavation." Carrilho da Graça Architects, "Musealisation of the Praça Nova Archaeological Site at Castelo de São Jorge,” El Croquis 170, I (2014): 191. 
succession of polycarbonate and timber covered spaces evolving around a patio is defined, based on the remains of each of the two excavated residential structures. The contrast between the contemporary and the already existing elements defines the atmosphere of these spaces, with the supporting structure still going unnoticed. Viewed from above, when accessing the archaeological site from its upper entrance, the pattern of rectangular timber surfaces outlined with white stripes that constitutes the volume's roof plane reproduces the layout of those structures. The transitory presence of an installation emanates from this work, all the more so because of the apparent perennial nature of the archaeological remains that surround it.

João Luís Carrilho da Graça's words provide an insight into his work's singular appearance. His architectural proposal by no means seeks to recreate an actual ancient Islamic dwelling. "[T] he canopy that shelters the Muslim domestic structures and frescoes was taken as an opportunity to reproduce, through a conjectural interpretation, its spatial experience. [...] Professedly abstract and scenographic, the white walls theatrify the domestic spatiality of the two excavated dwellings." 4

A particular feature contributing to this architectural design's singular appearance should be noted, however. Although it stands as a building, its interior spaces meant to be experienced, this work can also be seen as standing as a scale model - a large white cardboard, polycarbonate and timber scale model designed and executed at a 1:1 scale. Rather than just a random outcome, this is a fully embraced aspect of the design. When asked if his work could be read as a scale model, João Luís Carrilho da Graça answered categorically: "I even usually present it as a scale model! [...] It is a kind of scale model of what may have been there." 5

These seemingly provocative words might be considered as merely reflecting Carrilho da Graça's well-known penchant for scale models, but such words actually appropriately convey the meaning of his work on the Islamic remains. Having to present a speculative dwelling, with no recreation of an actual Islamic house being desired, the intervention can easily be seen as a three-dimensional representation - large enough to be walked through - of a hypothetical building. Like any architectural representation, the work also lends a presence to an absent architectural object through the act of replacing it. It stands as a presentation scale model of the design project for that object, a three-dimensional synthesis that is the culmination of the design process.

The design project for the musealisation of the Islamic residential remains in Praça Nova do Castelo de São Jorge plays deliberately with the limits of both an architectural object and an architectural scale model, so much so that one is left wondering whether one is experiencing an architectural object that

4. Ibid, 205.

5. Own translation. Original text: "Mas eu até costumo apresentar isso como uma maqueta! [...] É uma espécie de maqueta daquilo que poderá lá ter estado". Interview with João Luís Carrilho da Graça. In J. Duarte, Para uma Definição de Maqueta: Representação e Projecto de Objectos Arquitectónicos. Doctoral Thesis (Faculdade de Arquitetura da Universidade de Lisboa, 2016), 44 (annexes). 
was conceived as if it were an architectural scale model, or an architectural scale model that intimates that it is as an architectural object. There seems to be no clear distinction between architectural object and architectural scale model. The singularity of this design by João Luís Carrilho da Graça derives very much from its ability to make that play.

\section{An Architectural Scale Model's Ongoing Ambition}

Entering the territory of architectural objects may be considered to be an ongoing ambition for architectural scale models, as the aforementioned citation from Hubert ${ }^{6}$ would have one believe, but some architectural scale models seem to set out to challenge their representational condition. By virtue of their size and also of the materials they are built with, some scale models compel one to enter into them rather than just look at them, allowing for a comprehensive experience that emulates the experience that is supposed to be mada possible by the architectural objects they represent. The body is challenged to habitate those scale models, to immerse in their interior, to move through them, with the scale models thus becoming habitable objects. Even if such scale models do not find regular use, the history of architecture documents their adoption as a pervasive practice. Indeed, it was a practice adopted by Filippo Brunelleschi (1377-1446) for the dome of Florence Cathedral; by Michelangelo Buonarroti (1475-1564) for Saint Peter's Basilica; by Gian Lorenzo Bernini (1598-1680) for the Colonnade of Saint Peter's Square; by João Frederico Ludovice (16731752) for the Main Chapel of Évora Cathedral; by Mies van der Rohe (18861969) and Lilly Reich (1885-1947) for the House for a Childless Couple; and by I. M. Pei (1917- ) for the Louvre Museum extension; to mention only a few.

One question must thus be asked: are those objects still architectural representations, or have they crossed a line and become architectural objects?

Answering this question will require looking at how an object is signified, rather than at a set of intrinsic features pertaining to either an architectural object or an architectural scale model, for at question here is very much the possibility of an object being considered just as much as an architectural object as an architectural scale model.

Some background information on the inquiry as to how an object is signified can be found in Foucault's observations in L'Ordre du Discours, ${ }^{7}$ which he made after affirming the existence of a certain number of procedures with which all societies aim to control the production of discourse. In seeking to identify a way to overcome said procedures, Foucault calls for a new understanding of the relationship that is established between the discourse and the things of the world that the discourse reveals: "there is no pre-discursive fate disposing the world in our favour. We must conceive discourse as a violence that we do to things, or, at all events, as a practice we impose upon them; it is in this practice

6. Hubert, "The Ruins of Representation," 1981, 17.

7. M. Foucault, The Archeology of Knowledge \& the Discourse on Language (New York: Pantheon Books, 1972). 
that the events of discourse find the principle of their regularity." representation is not addressed by Foucault, and identification of the procedures with which control of its meaning is procured is not a focus of this paper, even if such procedures are also internalised by architectural representation. However, by denouncing the supposed natural concordance between discourse and the world standing as its object; by questioning the transparency with which the discourse provides access to understanding of the world; in short, by asserting the limitations of what is known about the world and how it is known, Foucault's exhortation proves its ability to serve as the backdrop to such an inquiry.

\section{Becoming an Object}

\section{The Status of the Objects}

A basic observation regarding the meaning of the objects must be acknowledged if an inquiry as on how an object is signified is to be pursued: an inherent meaning for an object cannot be taken into consideration, as it is not possible for an object to attribute a meaning to itself; objects are devoid of selfawareness. Thorough attention to the status of the object is required for such an inquiry to be pursued.

Janeiro's approach in Origens e Destino da Imagem: para uma fenomenologia $d a$ arquitectura imaginada ${ }^{9}$ to observation of the relationship that the subject conducts with the world that the subject takes part in and in which the subject defines themselfs - objects accordingly being considered as what the subject distinguishes from tehmselves ${ }^{10}$ - will be taken as a mainstay for the intended inquiry on the status of the objects.

Acknowledging that objects do not have an inherent meaning, the meaning of an object can be understood as being conferred upon it by the subject when appariseing it. "Therefore, one can consider that the object does not exist in itself, but that its conditions of existence are determined by the subject. It is by determining such conditions that the subject identifies the object and can read it; in a word, can represent it - when they see it, denominate it, assess it, describe it, draw it, photograph it, design it, etc. - thus being able to construe an image of it." If no such representation is accomplished, and no such image is construed, outside that of the representation, as representation is "the sole

8. Ibid, 229.

9. P. Janeiro, Origens e Destino da Imagem: Para uma Fenomenologia da Arquitectura Imaginada (Lisboa: Chiado Editora, 2010).

10. Ibid, 16.

11. Own Translation. Original text: "Assim sendo, podemos considerar que o objecto não é [...] em si mesmo, mas que é o sujeito quem lhe determina as condições de existência. É ao determinar essas condições que o sujeito detecta o objecto e o pode ler, em suma, o pode representar - quando o ve, nomeia, analisa, descreve, desenha, fotografa, projecta, etc. - e, assim, dele pode construir uma imagem." Ibid, 34. 
possible relationship between the subject and the object,"12 then there is no existence that would seem to be ascribable to an object.

Objects should be considered representational entities. That is how they acquire a meaning. Rather than an occasional condition, one driven by a circumstantial purpose, representation is a permanent condition of objects.

Submission to a continualy ongoing process of actualisation must be acknowledged as an underlying feature of representation; this means that the representation is successively accomplished and, therefore, also marked by constant modifications and subsequent revisions. Lyotard provides an insight into this continually ongoing updating process that objects always undergo. "The object exists as a "same" which is given to me throughout the continual modifications, and what makes it a thing for me (that is, in itself for me) is precisely the necessary inadequacy of my grasp of the object. [...] In other words, the object as it is given to me in perception is always open on the horizons of indetermination."13 This verification should be extended to cover reality, whereby reality is considered as encompassing all objects. Reality must also be regarded as a representational entity; that is also how reality acquires a meaning. "We can consider that reality, or, the thing, or, the way-the- "thing"appears-to-the-subject, is representation and does not exist outside the subject, as it is the subject who provides it with the conditions for such appearance or such representativeness." 14 Other than representation, therefore, there is no existence that would seem to be ascribable to reality.

The subject's individual dimension cannot be dissociated from the collective dimension - the recognition of reality as a representational entity having to be paralleled by recognition of it as a coded entity. The existence of a code ensures the attribution of meanings therefore allowing for them to be shared, without which no communication would be possible, be it between subjects or with oneself. Although the need for a code might seem superfluous in such personal communication, as the meanings are generated by the subject, the code allows for the very possibility of constitution of a meaning, other than of just confirming it. A possibility of order is provided to the things of the world by the existence of a code, comprehensibility being conferred to them even before communicability is enabled. This is a possibility that must be acknowledged as being provided first and foremost for the subject whenever they seek to comprehend the world they are immersed in. "To speak of the attribution of meaning is to speak of a code that enables such attribution and its consequent decoding. Therefore, everything to which culture has given a meaning to, we call reality - a cultural entity; or, in redundant terms, a culturally coded entity,

12. Own Translation. Original texto: "a única relação possivel entre o sujeito e o objecto." Ibid, 39

13. J.-F. Lyotard, Phenomenology (Albany: State University of New York Press, 1991), 48.

14. Own Translation. Original text: "Podemos considerar que a realidade, ou, a coisa, ou, o modo-como-a-"coisa"-aparece-ao-sujeito, é representação e não existe fora do sujeito, uma vez que é ele, o sujeito, quem lhe possibilita as condições desse aparecimento ou dessa representatividade." Janeiro, Origens e Destino da Imagem: Para uma Fenomenologia da Arquitectura Imaginada, 2010, 45. 
since the absence of a code implies the inability to signify." ${ }^{\prime 15}$ Culture can be thought of as the fabric encompassing all codes. Without the existence of a code, there seems to be no possibility of signifying objects and, therefore, of constituting reality. This condition is concomitant with the above-mentioned representational condition of reality.

\section{The Impossibility of an Absolute Reality}

One further question is still raised by the status of the objects, and, by extension, by the status of reality.

Although objects emerged as things that are constituted by the subject, their existence having to be perceived as an image construed by the subject whenever they are in front of or imagining said objects, an impression of the existence of an absolute reality, a repository of all its possible existences, may still persist. As Janeiro points out, "one has the idea that the object, reality in general, is something more, something more saturated."16 Lyotard's aforementioned "horizons of indetermination," "17 before which everything is constituted, contribute to the establishment of such a notion, as the overcoming of such indetermination, even if it always a provisional one, is justifiably determined by confronting the constitution of the things of the world with the completeness of the absolute reality.

The existence of such a something more must be assessed. If objects are what the subject signifies, the something more held by absolute reality must correspond to something that eludes the processes of signification that have been taken into consideration. Rather than something not yet signified, for in such case a signification is admissible, the something more must be acknowledged as something non-signifiable, i.e., something that allows no signification at all. The something more stands therefore as if it were a signification held exclusively by the absolute reality, with no access to it being possible for the subject. The subject is only permitted an intuition of it.

One must find in such seeming inaccessibility, however, the reason that calls into question the very existence of the something more. If its meaning is held only in itself, the something more and therefore the absolute reality considered in its completeness, cannot be reached by the subject by facing the world. However, "[w]e can only build knowledge on what we learn, on the experienced." ${ }^{, 18}$ It does not seem possible that any existence of such a something

15. Own Translation. Original text: "Falar de atribuição de significado, é falar de código que possa instituir essa atribuição de significado, e a sua consequente descodificação. Portanto, a tudo a que a cultura atribuiu significado chamamos realidade - uma entidade cultural; ou, redundantemente, uma entidade culturalmente codificada, uma vez que, a ausência de código implica a incapacidade de significar." Ibid, 40.

16. Own Translation. Original text: "tem a impressão de que o objecto, a realidade de um modo geral, é algo-mais, algo de mais saturado.” Ibid, 47.

17. Lyotard, Phenomenology, 1991, 48.

18. Own Translation. Original text: "Só podemos construir o conhecimento sobre o que apreendemos, sobre o vivido." Janeiro, Origens e Destino da Imagem: Para uma Fenomenologia da Arquitectura Imaginada, 2010, 48. 
more, of something that will always escape representation, can be sustained. Such an existence is from the outset betrayed by the fact that it is identified, for an identification also has to be acknowledged as a representation of the thing being identified. Rather than being held by reality, the something more must be thought of as being incorporated by the subject in the representations with which the subject construes what they consider to be the reality. "[T]he something more, if it is to be found, must be sought by the subject in themselves. The prospection of the something more must be implemented by the subject of the subject (on the subject; in oneself; oneself). In that search, the object will be a mere pretext for self-knowledge." 19

The impression of a higher saturation of reality should not be abandoned, however. Reality is indeed more saturated than all its representations - even the most complete ones; but that does not mean that reality does not have a representational condition. Reality and its representations have different degrees of saturation, but they all stand as representations, they all stand as differently saturated images construed by the subject about something that they have encountered or imagined.

\section{The Objects Revised}

Rather than existing prior to being perceived by the subject, reality is what the subject signifies whenever encoutering the world. Reality is therefore a representational entity rather than an entity in itself. Temporariness emerges as a defining feature of reality.

One always latent doubt, one that is grounded on the comprehension of reality as it has been considered, must be dispelled here: if reality is constituted as a representation and if a representation replaces its object, a return to the arguments supporting the existence of a reality other than the one conceived by the subject seems a justifiable one. A peremptory answer is given by Janeiro to this doubt. "Let us be clear: the image does not replace the object, but replaces the image constituted by the subject in the presence of the object." 20 If an object is actually present, if it is possible to confront it, a juxtaposition between the image created by confronting that object and the very confrontation that gives rise to the image is performed by the subject - the existence of the objects as representational entities should be remembered; if the object is an absent one, either because it is not present or because it does not exist, if it is not possible to confront it, a presence is granted to that object by the subject with recourse to an image stored in the memory that replaces the image that eventually would have been constituted had such an object been confronted.

19. Own Translation. Original text: "Portanto, o algo-mais, a ser encontrado, deve ser procurado pelo sujeito em si próprio. A prospecção do algo-mais deve ser instaurada pelo sujeito ao sujeito (no sujeito; a si próprio; em si). Nesta procura, o objecto será um mero pretexto de autoconhecimento." Ibid, 69.

20. Own Translation. Original text: "Esclareçamos: a imagem não fica em vez do objecto, mas fica em vez da imagem que o sujeito constitui em sua presença.” Ibid, 49. 
These processes should never be thought of as taking place in the now only, although now is when the constitution of the objects is precipitated. Rather than being limited to an instant, the constitution "is impregnated with time, i.e., it consists of a synthesis of the past and the future, whilst holding the opportunity of occurring at the present moment." ${ }^{21}$ Each image construed by the subject is part of a succession of other images construed by the subject, with each such succession of images being continuously criss-crossed with other successions of images. It is possible to incorporate that extension of time within the scope of Lyotard's aforementioned comments, with the existence of the object as a 'same' given to the subject throughout continual modifications being pointed out.

It must be made clear, however, what such an image - the image referred to by Janeiro ${ }^{22}$ in affirming the entity that such an image stands for in the process of grasping an object - reveals when revealing itself as reality.

A preliminary comment concerning the entity to which the properties revealed by such images belong is needed here. Although, colloquially, properties are referred to as belonging to the objects, they are in fact held by the image that grants said objects an existence. Beyond representation, it must be remembered, reality does not hold any property of its own, as no existence can be ascribed to it. The properties attributed to the objects are those found in such representations, no matter how they are formulated. Therefore, more important than finding out what such images are informed with, which depends on their formulation, a case-by-case examination thus being necessary to accomplish such an inquiry, one should endeavour to understand how they are informed, i.e., under what conditions such the constitution of such images is established.

Space and time form the continuum throughout which the subject unfolds their action, thus establishing the way they encounter and represent the world. The subject does not oppose the world; rather, they comprehend themselves, comprehending the world and comprehending themselves in such a world. Merleau-Ponty's words provide an insightful understanding of such a singular relationship. "I have only to see something to know how to reach it and deal with it, even if I do not know how this happens in the nervous machine. My mobile body makes a difference in the visible world, being part of it; that is why I can steer it through the visible." 23 Such is the condition in which the images as which obejcts are constituted are informed and therefore formed. "Objects appear in the world constituted by the subject as images that hold a virtual spatiality equivalent, or similar, to the spatiality represented when those objects were directly experienced by the subject at a given time - the time they enter the consciousness; a moment that has already taken place." ${ }^{24}$ From then

21. Own Translation. Original text: "está impregnada de tempo, ou seja, compõe-se de uma síntese do passado e do futuro, mas com oportunidade de ocorrer no momento actual." Ibid, 81.

22. Ibid, 49.

23. M. Merleau-Ponty, The Primacy of Perception: And Other Essays on Phenomenological Psychology (Evanston: Northwestern University Press, 1964), 162.

24. Own Translation. Original text: "Os objectos aparecem no mundo constituído pelo sujeito como imagens que possuem uma espacialidade virtual equivalente, ou semelhante, à espacialidade representada aquando da experiência directa perante eles em determinado momento - no momento 
on, the objects will be stored in the memory, as part of some of the abovementioned successions of images.

No object can be thought of as having an intrinsic meaning. To be a specific object is a temporary condition, lasting only as long as the meaning that allows for that specific existence is ascribed to it.

\section{Becoming an Architectural Scale Model}

\section{Architectural Scale Models' Temporariness}

As it is a model, an architectural scale model may be considered, in a broad sense and after Echenique, "a representation of reality, in which the representation is made by the expression of certain relevant characteristics of the observed reality and where reality consists of the objects or systems that exist, have existed, or may exist." ${ }^{25}$ Accordingly, in compliance with the revision of the status of the objects, the representation of an architectural object by a scale model must be considered as being realised by expressing, by the means of the image construed by the subject as which a scale model is constituted, certain relevant characteristics of the image construed by the subject as which the architectural object being represented is also constituted, be it an existing object, one that has existed, or one that may exist. In a representation, two distinct images are presented in a relationship with each other. Only by being distinct from its object can a representation replace it.

However, no sharing of properties should be sought between the images as which an architectural scale model and an architectural object are constituted, as properties can neither be transferred, nor reproduced. Only a coded equivalence of images, a strictly coded one and therefore also a strictly arbitrary one, can be considered here. Only on the basis of such an equivalence can the scale models of one and the same architectural object take on such different formulations, ranging from conceptual models to realistic miniatures. The still common belief in the natural resemblance that scale models have with architectural objects because they share a three-dimensional existence proves therefore to be untenable. No natural relationship can be found between an object and its representations. The completion of representation is decoupled from resemblance, as Goodman has already argued - "Plainly, resemblance in any degree is no sufficient condition for representation." 26

An object can be an architectural scale model because, according to a given system of codes, that is commonly recognised on a tacit basis, be it out of the habit or the context, that object is correlated with an architectural object, thus replacing

em que apareceram à consciência; um momento que já foi presente.” Janeiro, Origens e Destino da Imagem: Para uma Fenomenologia da Arquitectura Imaginada, 2010, 81.

25. M. Echenique, "Models: A Discussion," in Urban Space and Structures (ed.) L. Martin and L. March (Cambridge: Cambridge University Press, 1975), 164.

26. N. Goodman, Languages of Art: An Approach to a Theory of Symbols (Indianapolis and Cambridge: Hackett Publishing Company, Inc., 1976), 4. 
it. Only as lon as that system of codes remains in force can an object be perceived as an architectural scale model. The immediacy with which some objects are perceived as architectural scale models cannot be mistaken for an evidence of an intrinsic signification held by said objects.

Identifying the wide range of codes used in architectural scale models falls beyond the scope of this paper. Nonetheless, their lack of uniformity and above all their lack of comprehensiveness must be acknowledged. The signification of an architectural scale model's form is just as much subjected to a code as its expression is. Also beyond the scope of this paper is a thorough discussion of the arguments supporting the arbitrariness of the relationship that a scale model has with an architectural object. Nonetheless, it can be emphasised that that arbitrariness is the consequence of the absence of any natural link - i.e., a noncoded relationship - between a representation and the object being represented. A scale model and the architectural object it represents are just as much distinct from each other as they are independent entities of one another, and this is confirmed by the possibility of achieving a reciprocally autonomous comprehension of one from the other. As to the immediacy with which most architectural scale models are usually understood, it must be acknowledged that the interpretation process demanded by scale models is learned early in life, commonly with toys as pointed out by Selenitsch. ${ }^{27}$ It becomes such an imperceptible process. The difference between a toy - a small car or a doll, for instance - and an architectural scale model should be sought in the objects being represented and in the reasons calling for said representations, rather than in how representation is accomplished in either case. No equivalent advanced acquaintance with the codes used in architectural drawings, particularly in technical ones, can be identified, resulting in their common lesser immediacy.

Following the foregoing observations, the understanding of an architectural scale model must be considered as involving the control of a certain system of codes. As that control is guaranteed, it will then be possible to interpret an object as a scale model, discerning in it an architectural object. However, still following those observations, the systems of codes that enable such interpretations do not belong to the objects. Objects are submitted to them, thereby becoming meaningful entities. Therefore, considering that objects do not appear before the subject already holding a meaning, with the meaning of an object instead being assigned to it by the subject, and considering also that objects are assigned a meaning insofar as they are coded, if an object is interpreted as a scale model of an architectural object it is because, within a certain context and for a certain purpose, that object was subjected to a system of codes that allows for that interpretation. No object can be taken as intrinsically being an architectural scale model; such signification can never be taken for granted. And that being the case, any object may be constituted as an architectural scale model, for the existence of an architectural scale model is determined by the assumption of a given system of codes, rather than by an intrinsic feature pertaining to that

27. A. Selenitsch, "Small Real Large," in Homo Faber: Modelling Architecture (ed.) M. Burry, M. Ostwald, P. Downton and A. Mina (Melbourne; Sydney: SIAL and the Melbourne Museum; Archadia Press, 2007), 5. 
object. The inadequacy of a given object as a scale model of an architectural object must not be mistaken for the impossibility of said object becoming an architectural scale model.

Eco's considerations on the notion of the sign support the acknowledgement of an architectural scale model as a signification conferred to an object and the temporariness of that signification. The observation that a sign is always the result of a conventional correlation between some elements from an expression plane and some elements from a content plane leads Eco to a twofold conclusion: "a) a sign is not a physical entity, the physical entity being at most the concrete occurrence of the expressive pertinent element; b) a sign is not a fixed semiotic entity but rather the meeting ground for independent elements (coming from two different systems of two different planes and meeting on the basis of a coding correlation.)" ${ }^{, 28}$ Rather, a sign reveals itself as "the provisional result of coding rules which establish transitory correlations of elements, each of these elements being entitled to enter - under given coded circumstances - into another correlation and thus form a new sign." $" 29$ There is a thin line between a set of cardboard pieces and an architectural scale model.

Architectural scale models must be acknowledged as objects holding a temporary existence. Signifying certain objects as architectural scale models is circumstantial volition.

\section{Architectural Scale Models’ Ambiguity}

A degree of ambiguity relating to the architectural scale model's status must be addressed if the signification of an object as an architectural scale model is to be understood. The architectural scale model's three-dimensional existence has once again to be taken into consideration.

The possibility of the relationship that a scale model has with an architectural object being facilitated due to their common three-dimensional existence has already been dispelled. A coded equivalence between the images one and the other are constituted as allows for that relationship - a strictly coded equivalence and therefore also a strictly arbitrary one, it must be reiterated. A movement away from the sphere of architectural representation into the realm of architectural objects seems, however, to be implied by the fact the architectural scale models have such an existence, moreover because the construction dimension that underlies the scale model is readily acknowledged - a rightfully insinuated movement, one could considered. "Of all [...] forms of representation, the model is the only physical, three-dimensional realization of the architect's idea - which, after all, is ultimately intended to be a physical, three-dimensional thing." 30 As Hubert points out, after elaborating on the notion quoted at the beginning of this paper, "[p]erhaps the model concretizes the ontic condition of the project. It exists as desire - in a kind of atopia, if not utopia. It holds out the promise of

28. U. Eco, A Theory of Semiotics (Bloomington: Indiana University Press, 1979), 49.

29. Ibid.

30. K. Moon, Modeling Messages: The Architect and the Model (New York: The Monacelli Press, 2005), 11. 
inhabitation, even it if does not fully afford it." 31 Architectural scale models" representational condition becomes diffused, if not to say dissolved, therefore a singular status may have to be agreed upon for them. "For the space of the model lies on the border between representation and actuality. Like the frame of a painting, it demarcates a limit between the work and what lies beyond. And like the frame, the model is neither wholly inside nor wholly outside, neither pure representation, nor transcendent object.",32

Whilst always a latent presence in all architectural scale models, the weaker the intent to realisation a design project is the more evident the dissolution of the scale models' representational condition seems to be. The concretness of a scale model may even emerge as a quasi-architectural aspect, as scale models are fequantly chosen as the ultimate embodiment of the architect's work. That is the case of Kazimir Malevich's (1878-1935) 1920s Arkitectons, a set of "threedimensional compositions, rough models of original architectural compositions.",33 With no buildings actually being defined, the Arkitectons became the architectural concretisation of Malevich's ideas. The same goes for Peter Eisenman's (1932- ) axonometric model of 1975 House X, designed for Bloomfield, Michigan, USA, its representational status deliberately being relinquished. Eisenman's understanding of architecture as being self-referential rather than symbolic of man, freed both architecture and the manipulation of the elements which it is constituted of - walls, pillars, beams - from scale specificity, thus making a distinction between architectural objects and architectural scale models irrelevant. A homological relationship between one and the other was advanced, with the model emerging just as much a cornerstone of the architect's thinking as the final objective. "My concern with the model could be understood in two ways. One would be as a representation of ideas (as opposed to of buildings). [...] The second would be the model as an idea in itself, an object as was the case with the House X model. It is not a representation of anything., ${ }^{34}$

The representational condition of the architectural scale model needs, however, further assertion. The meaning of an object has already been established as being determined by the subject whenever they encounter or imagine it. That is how objects acquire an existence. An object may therefore be invested with architectural properties and be part of architectural imagery without actually representing an architectural object as Malevich's Arkitectons and Eisenman's model for House X do. However, one condition must be emphasised if an object is signified as an architectural scale model: it stands for an architectural object; it replaces it - the term 'architectural object' is used in the broadest sense, encompassing both actual buildings and architectural concepts. Without the replacement element, no architectural scale model as such would be achieved. That is the consequence of being a representation - an architectural

31. Hubert, "The Ruins of Representation," 1981, 17.

32. Ibid.

33. S. Khan-Magomedov, Pioneers of Soviet Architecture (New York: Rizzoli, 1987), 63.

34. P. Eisenman, "The Poetics of the Model: Eisenman's Doubt," in Idea as Model (ed.) K. Frampton and S. Kolbowski (New York: Institute for Architecture and Urban Studies and Rizzoli International Publications, 1981), 121-122. 
representation, in this particular case. This is a defining feature for architectural scale models, no matter the material used to make them or their size; or the purpose they are meant to serve; or even the accuracy and the concreteness with which their object is defined. Even where the expression of a more abstract architectural relationship is the concern, the fact that the scale model's order of magnitude is usually smaller than the architectural object's, reinforces the claim that such a replacement is executed.

An architectural scale model is an object that makes an architectural object present. The image that an architectural scale model is constituted as appears as the image that an architectural object is constituted as; the former is taken as the latter - it allows for a foretatste of it. A relationship between two distinct objects - two reciprocally autonomous objects one of which may even not exist, one must reiterate here - is established whenever an object is perceived as an architectural scale model.

A movement away from the sphere of architectural representation into the realm of the architectural objects is in fact insinuated by architectural scale models by emulating their object with such a singular concreteness. However, no dissolution of the scale model's representational condition can be considered as a result of this. As Hubert points out after identifying the ambiguity of the model's space, "[the model] claims a certain autonomous objecthood, yet this condition is always incomplete. The model is always a model of. The desire of the model is to act as a simulacrum of another object, as a surrogate which allows for imaginative occupation." ${ }^{, 35}$

Insight into the meaning of the 'objecthood' claimed by the model is provided by Fried's 'Art and Objecthood, ${ }^{36}$ and Hubert's reference to this notion is likely based on it. Objecthood is identified by Fried as being embraced by Minimalist Art, or Literalist Art, as Fried prefers to call it, as Minimalist Art claims that its proposals are constituted as single shapes holding no other values than those emerging from experiencing it in situ as strict objects - a theatrical experience, as Fried deems it. A new perspective was sought for art, given that painting and sculpture - and Fried gives the examples of Donald Judd (1928-1994) and Robert Morris (1931- ) - were confined to an addition of parts, conflicting their hierarchical relations with the whole of the work. Fried questions the results of the Minimalist project, pointing out its apparent inner contradictions. "The shape is the object: at any rate, what secures the wholeness of the object is the singleness of the shape. It is, I believe, this emphasis on shape that accounts for the impression, which numerous critics have mentioned, that Judd's and Morris's pieces are hollow." 37 'Art' and 'objecthood' are perceived as being at odds with each other, Minimalist Art being seen by Fried as being anti-ethical to Art, as the reduction of painting and sculpture to the condition of mere objects goes against their own ontological raisons d'être.

35. Hubert, "The Ruins of Representation," 1981, 17.

36. M. Fried, Art and Objecthood: Essays and Reviews (Chicago and London: University of Chicago Press, 1998).

37. Ibid, 151. 
Hubert's reference to the 'objecthood' claimed by architectural scale models does not involve a literal interpretation of Fried's understanding of the notion. However, a new horizon for the latter may be envisioned in accordance with the former. No longer is it about acknowledging the ambiguity of the space of the architectural scale model in the movement it insinuates away from the sphere of architectural representation into the realm of the architectural object; with such movement insinuated, it is also about acknowledging the confrontation with the spectrum of the scale model's pointlessness. "The truth of the model does not lie in its referential nature since as simulacrum the model denies the possibilities of its own autonomous objecthood and establishes the building as the ultimate referent, as a reality beyond representation."38 Architectural scale models are confirmed as belonging to the sphere of architectural representation, despite all efforts to escape it - in the end, the frame goes with the painting...

No use can be found in terms of the envisioning of architecture in an object that is incapable of revealing an architectural object, regardless of whether that architectural object is an actual building or an architectural concept.

\section{Body Challenges}

The investigation of the status of the objects - one should bear in mind made it possible to clarify that, the existence of an object is provided by the subject whenever they signify it, as objects have no intrinsic meaning of their own. To be a specific object is a temporary condition, lasting only as long as that specific meaning is ascribed to it. An object's existence - its apparent existence is always a circumstantial one.

Architectural objects should be understood in accordance with this revision of the status of the objects - with a stricter sense of the term as an actual building now being considered. No object can be acknowledged as being intrinsically an architectural object. The existence of an object as an architectural object is determined by the subject whenever they encounter that object. To be an architectural object is also a temporary condition, no matter how evidently some objects stand as architectural objects. However, one must affirm one feature that distinguishes an architectural object from all other objects: the ability to embrace the subject. "[O]f all the objects of the world, architectural objects do not (only) live in the world beside us [as all other objects do]; it is us who live in them, not just beside them, but also, if not to say, above all, inside them." 39 One can discuss the conditions that facilitate such an embrace and what it implies, but only thus, by embracing the subject, by becoming an extension of them and being the frame to their existence, can the existence of an abject as an architectural object be fully consummated, as "[ $t]$ he timeless

38. Hubert, "The Ruins of Representation," 1981, 19.

39. Own translation. Original text: "de todos os objectos do mundo, os objectos arquitectónicos, não habitam (só) ao nosso lado o mundo; somos nós que habitamos neles, não somente ao seu lado, mas também, senão mesmo sobretudo, dentro deles." Janeiro, Origens e Destino da Imagem: Para uma Fenomenologia da Arquitectura Imaginada, 2010, 15. 
task of architecture is to create embodied and lived existential metaphors that concretise and structure our being in the world." 40

This paper is about objects holding a singularity. It is about objects, one should bear in mind, that by virtue of their size and also the materials they are built with call into question the frontier between the universe of architectural representation and the universe of architectural objects; it is about objects that can become meaningful as architectural scale models just as much as they can as architectural objects. Instead of just being looked at, these objects challenge the body to live inside them, to immerse itself in their interior, to move through it, requiring a reversal of the regular sense of possession established between a scale model and its beholder: no longer is it about an object being possessed by the subject whenever they encounter it, even because the full-model's "presence is remote from any sense of possession: it is not held within us." ${ }^{41}$ Rather, it is about the subject being possessed by an object as they let themselves inhabit it, thus seeing it as an extension of the body. "Understanding architectural scale implies the unconscious measuring of the object or the building with one's body, and of projecting one's body scheme into the space in question. We feel pleasure and protection when the body discovers its resonance in space." 42

Are such objects still architectural representations, or have they crossed a line into the realm of architectural objects? I posed this question at the beginning of this paper. The answer to that question must be sought not in said objects but in how the subject choses to signify them. It is the willingness to assume such objects either as a substitute for an architectural object or as an extension of the body that grants said objects an existence either as an architectural scale model or as an architectural object.

The possibility of those objects becoming either an architectural object or an architectural scale model depends on how the body challenges itself to be embraced by them.

\section{Final Considerations}

A few final words on the project for the musealisation of the Islamic residential remains in Praça Nova do Castelo de São Jorge, regarding the play with the boundaries of both architectural object and architectural scale model that confers the design its singularity.

There is indeed a deliberate playing the boundaries of both the architectural object and the architectural scale model in the design, with no clear distinction between one and the other seemingly discernible. However, it is ultimately the confirmation of that distinction rather than the dissolution of it that underlies that play. No matter how appealing the affirmation of a dissolution may seems to be, only the distinction between architectural object and architectural scale

40. J. Pallasmaa, The Eyes of the Skin: Architecture and the Senses (Chichester: John Wiley and Sons, 2012), 76.

41. Moon, Modeling Messages: The Architect and the Model, 2005, 73.

42. Pallasmaa, The Eyes of the Skin: Architecture and the Senses, 2012, 71-72. 
model provides the appropriate framing for the understanding of the design proposal. The musealisation of the Islamic residential remains is understood alternately either as an architectural object, or as an architectural scale model, not simultaneously as one and the other. Therein lies the singularity of this work by João Luís Carrilho da Graça.

\section{Acknowledgements}

This work is financed by national funding from FCT - Foundation for Science and Technology under the Project UID/AUR/04026/2013.

The author wishes to thank Fernando Guerra |FG+SG for the photography of the Musealisation of the Islamic residential structures at Praça Nova do Castelo de São Jorge, Lisbon.

\section{Bibliography}

Carrilho da Graça Architects. "Musealisation of the Praça Nova Archaeological Site at Castelo de São Jorge.” El Croquis 170, I (2014): 190-207.

Duarte, J. Para uma Definição de Maqueta: Representação e Projecto de Objectos Arquitectónicos. [Towards a Definition of Scale Model: Representation and Design of Architectural Objects.] Doctoral Thesis. Faculdade de Arquitetura da Universidade de Lisboa, 2016. Available at: https://www.repository.utl.pt/ handle/10400.5/13708.

Echenique, M. "Models: A Discussion." In Urban Space and Structures. Edited by L. Martin and L. March. Cambridge: Cambridge University Press, 1975, 164-175.

Eco, U. A Theory of Semiotics. Bloomington: Indiana University Press, 1979.

Eisenman, P. 1981. "The Poetics of the Model: Eisenman's Doubt." In Idea as Model. Edited by K. Frampton and S. Kolbowski. New York: Institute for Architecture and Urban Studies and Rizzoli International Publications, 1981, 121-125.

Foucault, M. The Archeology of Knowledge \& the Discourse on Language. New York: Pantheon Books, 1972.

Fried, M. Art and Objecthood: Essays and Reviews. Chicago and London: University of Chicago Press, 1998.

Goodman, N. Languages of Art: An Approach to a Theory of Symbols. Indianapolis and Cambridge: Hackett Publishing Company, Inc., 1976.

Hubert, C. "The Ruins of Representation." In Idea as Model. Edited by K. Frampton and S. Kolbowski. New York: Institute for Architecture and Urban Studies and Rizzoli International Publications, 1981, 17-27.

Janeiro, P. Origens e Destino da Imagem: Para uma Fenomenologia da Arquitectura Imaginada. [Origins and Destination of the Image: Towards a Phenomenology of the Imagined Architecture.] Lisbon: Chiado Editora, 2010.

Khan-Magomedov, S. Pioneers of Soviet Architecture. New York: Rizzoli, 1987.

Lyotard, J.-F. Phenomenology. Albany: State University of New York Press, 1991.

Merleau-Ponty, M. The Primacy of Perception: And Other Essays on Phenomenological Psychology. Evanston: Northwestern University Press, 1964.

Moon, K. Modeling Messages: The Architect and the Model. New York: The Monacelli Press, 2005.

Pallasmaa, J. The Eyes of the Skin: Architecture and the Senses. Chichester: John Wiley and Sons, 2012. 
Selenitsch, A. "Small Real Large." In Homo Faber: Modelling Architecture. Edited by M. Burry, M. Ostwald, P. Downton and A. Mina. Melbourne; Sydney: SIAL and the Melbourne Museum; Archadia Press, 2007, 4-9. 